FACTA UNIVERSITATIS

Series: Visual Arts and Music Vol. 4, No 1, 2018, pp. 11 - 16

https://doi.org/10.22190/FUVAM1801011M

Original scientific paper

\title{
ART THROUGH THE PRISM OF CULTURAL NEWS PROGRAM UDC 659.3\%.4:7 RTS
}

\author{
Marta Mitrović, Tatjana Vulić \\ University of Niš, Faculty of Philosophy, \\ Department of Communication Sciences and Journalism, Serbia
}

\begin{abstract}
Public broadcasters have the professional responsibility and legal obligation to report on topics of public interest, including topics related to culture and, more specifically, arts, in order to meet communication needs of people, as reflected in the three main roles of the media: information, education and entertainment. In this paper, the authors investigated whether and to what an extent the Cultural News Program of Serbian Radio and Television reports on different types of arts, the achievements of artists and their works, the cultural policy of Serbia, and whether this program meets one of the basic objectives of journalism - education. The results of the monitoring clearly indicated that diverse and different types of art were reported on, but they also showed that there was marginalization of topics related to cultural policy.
\end{abstract}

Key words: art, culture, Cultural News, Radio-Television of Serbia, public broadcasters, media

\section{INTRODUCTION}

Since television is still the most influential electronic medium when it comes to shaping and influencing public opinion, this medium is without any doubt of immense importance for the presentation of cultural news. As television is direct and visual, it brings forth works of art by means of news analysis and criticism, as well as culture closer to viewers. The final third of newscasts is usually reserved for culture-related news, or special programs dedicated only to culture.

When it comes to commercial television stations in Serbia, as well as worldwide, culture and arts tend to be marginalized, suppressed and replaced by reality TV shows and other entertainment formats due to competing for the highest ratings and the most expensive advertising slots. However, public broadcasters have a professional responsibility and legal

Received July, 2018 / Accepted October 2018

Corresponding author: Tatjana Vulić

University of Niš, Faculty of Philosophy, Department of Communication Sciences and Journalism, Serbia

E-mail: tatjana.vulic@filfak.ni.ac.rs 
obligation to report on topics of public interest, including topics related to culture and, more specifically, arts, in order to meet communication needs of people, as reflected in three main roles of the public media: information, education and entertainment. Cultural topics, broad in content and form, aim at covering these three roles. Namely, one of the basic needs of the audience (well-informed, educated and critically-minded people) is to be informed about cultural and art-related events. In order for the viewers to be simply informed, it would be enough to have only detailed and exhaustive reports, or brief news. However, in order to educate the audience as well, public broadcasters should offer an analytical approach to these topics by using serious criticism. Moreover, wrongly perceived as intended only for the most educated group of viewers, culture and art topics do not need to include only professional essays and reviews. They can also be fun depending on journalists' creative approach.

In this context, culture and the fields it includes cannot be observed and discussed in a simple and monotonous way. Cultural topics need to be discussed from a much wider and more meaningful aspect. Frank J. Lechner and John Boli regard culture as "socially constructed and socially shared symbolism" (Lechner and Boli 2006, 44). These authors believe that culture has an important role in the creation of cultural forms that have a dynamic of their own, which then create the common elements shared within a society. These elements become important for a society or community "primarily through the work of institutions that carry abstract ideas into practice" (Lechner and Boli 2006, 44). In that sense, we can say that television is an indispensable link between art, artists, institutions and the general public.

"The splendour of theatre premieres, the grandeur of spiritual music concerts, the glamour of film festivals, the dedicated silence of national libraries... in one word - culture. Yet culture is not only about these things. Culture also includes devoted fieldwork by archaeologists and interpreters of ancient manuscripts, but also the efforts to attract visitors and readers to see valuable works of art in libraries and museums. Therefore, culture includes superb works of art created by great thinkers and artists, but also the efforts that culture reaches the largest possible audience in the form of books and thousands of their copies. Thus, culture also includes advertisements which, via press, radio and television, invite people to promotions, exhibitions, theatres " (Dragićević-Šešić and Stojković 2007, 7).

Hence, culture by itself, as well as everything that it involves ceases to be reserved only to the upper classes of society. Culture is also intended for "ordinary people". In one word, it is intended for everyone. Mass media have made it easily accessible. The language of journalists adapted and brought closer the most abstract artistic ventures to the audiences, to the broadest audience possible. This audience is not homogeneous and professional, it is a heterogeneous group of different types of people. It is not easy for a professional journalist to use simple language to explain very complex and abstract works of art - only the best can manage to do this successfully. Therefore, culture is intended for everyone, it makes a society connected and compact. Culture is also important for preserving a nation's tradition. Jacques Dugast says that "A nation's culture includes characteristics of different traditions" (Dugast 2007, 12). By reporting on culture (different arts and cultural policy), television encourages the creation of the cultural patterns of citizens, as well as the preservation of national culture and tradition. Similar to religion, science, and philosophy, arts belongs to culture, and out of the culture itself we can neither understand nor observe art. At the same time, arts define culture more closely. Encyclopaedia Britannica ${ }^{1}$ defines the concept of the arts as "modes of expression that use skill or imagination in the creation of aesthetic

${ }^{1}$ https://www.britannica.com/ 
objects, environments, or experiences that can be shared with others". Art is complex and diverse in its genres and forms, while at the same time each new era brings about the development of some new type of art. Arts include: literature, painting, sculpture, drawing, graphic design, photography, printing, ceramics, digital art, music (classical, pop, rock, folk, etc.), game design, ballet, opera, installation art, poetry, film, theatre, architecture, cartoons, graphite, origami, mosaic, email art, media, advertisements, comic books, etc. In this paper, the authors will investigate whether and to what an extent the Cultural News program of Radio Television Serbia reports on different types of arts, the achievements of artists and their works, the cultural policy of Serbia, and whether this program meets one of the basic objectives of journalism - education.

Serbian authors have not so often dealt with this topic, so the number of studies on the connection between television and arts, that is, on specialized television shows and arts is small. One such example is the monitoring conducted by Rade Veljanovski and Dubravka Valić-Nedeljković $\left(2015^{2}, 2016^{3}\right)$. Their publications, the monitoring of the National Public Broadcaster in Serbia and the Public Broadcaster in Vojvodina, also include findings on the reporting by the Cultural News Program of Radio Television Serbia. Their results indicated that the communication needs of viewers with regards to cultural information were met. "Among the values promoted, one of the most prominent values is fostering national culture and creativity, which is in accordance with the supposed role and legal obligation of public broadcasters. However, other universal values promoted by global and European culture, as well as the culture of the region were not ignored either" (Veljanovski and ValićNedeljković 2016, 7). Still, their studies do not include a specific analysis of art-related topics, that is, the level of representation and manner of reporting on different types of arts. This is where we aim this research to make a significant contribution.

\section{RESEARCH}

In February 2014, a specialized thematic program called Cultural News started to be broadcast as part of the informative program of the National Public Broadcaster in Serbia. It is a daily broadcast after the Late-night news, while the rerun is the following day after the Morning News. Cultural News program usually has a 15-minute time slot; however, depending on the daily events, it often lasts longer. The topics covered in Cultural News are mostly important events regarding national culture, the art work of our cultural workers, artists, cultural events from around the globe, as well as pop culture, popular music, etc. By respecting its professional role and legal obligations, Cultural News promotes values that foster and nurture national culture and creativity, as well as other universal cultural values. This television show primarily covers daily reports of current events; however, a critical review of current events is also present. The techniques used are diverse, but like any other informative television show, the most common techniques used are reports, news package, news and interviews. Besides the National Public Broadcaster Internet page ${ }^{4}$, the Cultural News program is also available on YouTube .

\footnotetext{
${ }^{2}$ See: http://www.novinarska-skola.org.rs/sr/wp-content/uploads/2015/10/Izvestaj-o-monitoringu-programskihsema-Radio-televizije-Vojvodine-i-Radio-televizije-Srbije-oktobar-2015.pdf, viewed on 27/7/2018.

${ }^{3}$ See: http://www.novinarska-skola.org.rs/sr/wp-content/uploads/2016/10/FR4.pdf, viewed on 27/7/2018.

${ }^{4}$ See: http://www.rts.rs/page/tv/sr/series/20/rts-1/4200/kulturni-dnevnik.html, viewed on 26/7/2018.

${ }^{5}$ See: https://www.youtube.com/watch?v=HQGLIb9lsWc, viewed on 26/7/2018.
} 
The overall goal of this research was to analyse the coverage of and reporting on artrelated topics in the Cultural News. The coding sheet used for the purposes of this research classified all Cultural News episodes based on the type of art they reported on. Our goal was to identify the types of art which were most frequently spoken about, as well as those which were marginalized. Therefore, the specific goals of this research were to:

1. Identify the extent to which art is reported on in the Cultural News

2. Identify the types of art most frequently spoken about in the Cultural News

3. Identify the topics which were marginal or ignored in the Cultural News.

\subsection{Sample}

For the purposes of this research, we conducted monitoring of the Cultural News program in May 2018 (from May 1 to May 31). This month was selected since many cultural events are organized in several cities in Serbia, which, based on the evaluation criteria are not only of local, but also of national significance. Since Cultural News is an informative television show prepared by the RTS Public Broadcaster which presents culture-related topics only, it is expected to include cultural events of national importance in its program as well. A total of 23 Cultural News television shows were analysed, which included 170 TV features.

\subsection{Method}

The coding sheet was created for the purposes of this research and it was used to obtain research results which were further analysed using standard methods. We used quantitative and qualitative content analysis, while the unit of analysis was each individual TV feature.

\subsection{Results and discussion}

Based on the research goals set, the monitoring we conducted between May 1 and May 31, 2018 indicated that diversity was present with regards to reporting on different types of art (See Fig. 1).

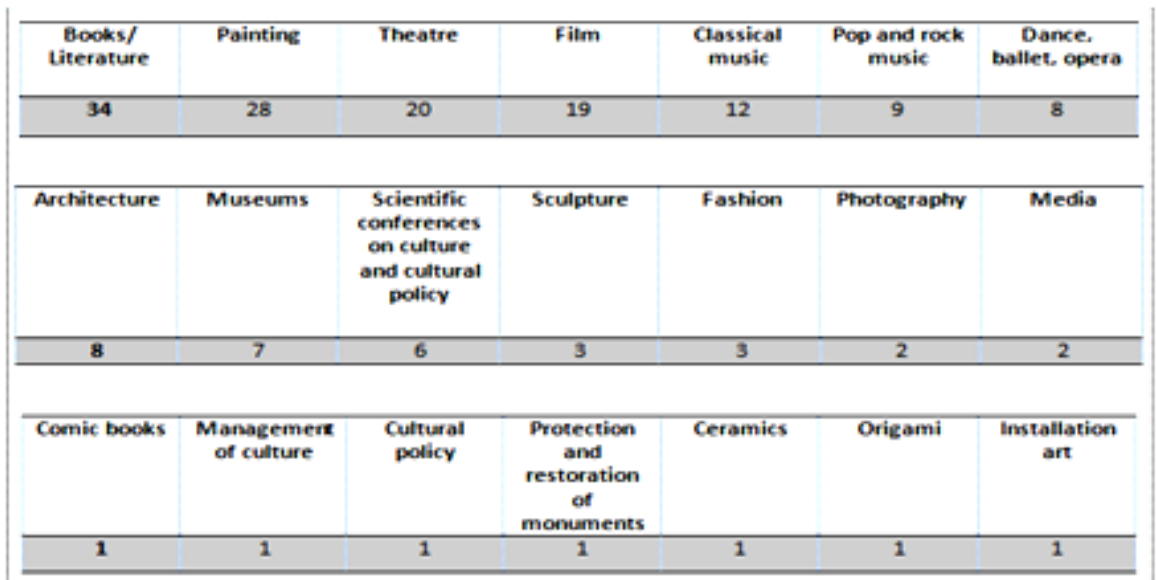

Fig. 1 Quantitative overview of TV features shown in the Cultural News - based on art type 
The most common topics were books-literature (34 features), painting (28), theatre (20) and film (19 features). As for classical music, there were 12 features shown, pop and rock music were presented in 9 features, while dance, ballet and opera were spoken about in a total of $8 \mathrm{TV}$ features. These art types are also the most common ones in other media as well (Vulić 2017). Museums were spoken about in 7 TV features. We expected it since "the Night of Museums" event was traditionally organized in May in more than 70 towns and cities. With regards to this topic, we noticed that it was not presented frequently enough in the Cultural News, that is, museums located outside of Belgrade were not reported about sufficiently. For example, only one TV feature (out of seven) reported on "the Night of Museums" in other cities and towns in Serbia.

The International Architecture Week is traditionally celebrated in May as well, so this type of art was presented in eight TV features, which talked about the latest achievements in this field, both globally and in our country.

The viewers of Cultural News were able to watch three TV features which talked about sculpture exhibitions, as well as three more features which talked about fashion, while photographs and media (printed media and television) were covered by two features each. Six news reports talked about scientific conferences dealing with culture and cultural activities organized in Belgrade, while comic books, management of culture, cultural policy, protection of monuments, ceramics, origami and art installations were dedicated only one TV feature each.

Based on the monitoring of the Cultural News conducted in May, we can conclude that different types of art were truly reported on in this television show. Moreover, it can be clearly noticed which art types are marginalized. For example, photography was only dedicated two TV features, while comic books, although recognized as the "ninth art", were spoken about only in one. This might have been the case since no events related to these types of art took place in May. On the other hand, we feel the need to emphasize the marginalization of cultural policy and management of culture topics. Is everything truly so perfect with regards to culture in Serbia, or is there simply no interest among Cultural News editorial staff to investigate these topics? It is, however, more likely that the editors decided to ignore the topics that require a search for answers which could solve the accumulated culture-related problems.

\section{CONCLUSION}

In an abundance of television shows characterized by kitsch and "art trash" broadcast on commercial television stations, the National Public Broadcaster of Serbia is the only source of culture and education-related topics for television audiences, and it is considered a type of balance between culture and kitsch. This kind of balance is very important. This concept is emphasized by Gladkova (2013) as well, and she claims that the effect of television watching on the perception of social reality cannot be underestimated by any means and at any moment. Todorović also says: "We learn about the world around us through images and sounds that surround us, and we also communicate with each other using sounds and images. We absorb these images and sounds with our eyesight and hearing sense, which are sensitive to certain frequencies that the eye-brain and ear-brain systems can decrypt and turn into cognitive observations" (Todorović 2009, 274). 
The research we conducted has shown us that the Cultural News program helps to properly educate and inform the citizens of Serbia about achievements and activities related to different types of art and artists both from Serbia and around the world. The results clearly indicate that different types of art were reported about; however, we would like to emphasize that the Cultural News editors should report more on analytical topics related to cultural policy and accumulated problems in our national cultural institutions, as well as to indicate the need for the government to invest more in art projects and culture-related projects in general. Mere reports on art and culture become useless if they are not put into the appropriate context, which would imply the circumstances under which art is created and exists in a country.

\section{REFERENCES}

Britanica [Online]: https://www.britannica.com/

Diga (Dugast), Ž (J). (2007). Kulturni život u Evropi na prelazu iz 19. u 20. vek. Beograd: Clio

Dragićević-Šešić, M., Stojković, B. (2007). Kultura - menadžment, animacija, marketing. Beograd: Clio

Gladkova, A. A. (2013). The role of television in cultivating the values of pluralism and cultural diversity in children, Psychology in Russia: State of the Art, Vol. 6, No. 1: 138-143.

Lečner (Lechner), F., Boli (Boli), Dž (J). (2006). Kultura sveta. Beograd: Clio

Todorović, A. L. (2009). Umetnost i tehnologija komunikacija. Beograd: Clio

Valić-Nedeljković, D, Veljanovski, R. (2015). Izveštaj o monitoringu programskih šema radio-televizije Vojvodine i Radio-televizije Srbije kao indikator ostvarivanja zakonskih funkcija javnih medijskih servisa. Novi Sad: Novinarska škola http://www.novinarska-skola.org.rs/sr/wp-content/uploads/2015/10/Izvestaj-omonitoringu-programskih-sema-Radio-televizije-Vojvodine-i-Radio-televizije-Srbije-oktobar-2015.pdf

Veljanovki, R., valić-Nedeljković, D. (2016). Kutura na javnim servisima - analiza programa Radio-televizije Srbije i Radio-televizije Vojvodine. Novi Sad: Novinarska škola http://www.novinarska-skola.org.rs/sr/wpcontent/uploads/2016/10/FR4.pdf

Acknowledgement: The paper is a part of the projects supported by the Ministry of Education and Science of the Republic of Serbia: Sustainability of the Identity of Serbs and National Minorities in the Border Municipalities of Eastern and Southeastern Serbia (179013), conducted at the University of Niš - Faculty of Mechanical Engineering and project Civil society and religion (179008), done by the University of Belgrade - Faculty of Political Sciences and the University of Niš - Faculty of Philosophy.

\section{UMETNOST KROZ PRIZMU KULTURNOG DNEVNIKA}

Javni servisi imaju profesionalnu i zakonsku obavezu da izveštavaju o temama od javnog interesa, među kojima su i teme iz oblasti kulture, $i$ umetnosti, i na taj način ispune komunikacione potrebe građana, koje se ogledaju kroz tri osnovne uloge javnih servisa: informisanje, edukaciju i zabavu. $U$ ovom radu autorke su istraživale da li i u kojoj meri Kulturni dnevnik Radio televizije Srbije izveštava o različitim vrstama umetnosti, dostignućima kulturnih poslenika - umetnicima i njihovim delima, kulturnoj politici Srbije kao i da li na taj način ispunjava jednu od osnovnih funkcija novinarstva obrazovnu. Rezultati sprovedenog moitoringa jasno su ukazali na raznovrsnost, kada je reč o izveštavanju o različitim vrstama umetnosti, ali i na marginalizaciju tema koje se bave kulturnom politikom.

Ključne reči: umetnost, kultura, Kulturni dnevnik, Radio televizija Srbije, javni servis 